\title{
The musical circle: The umwelt theory, as applied to zoomusicology
}

\author{
Dario Martinelli
}

\begin{abstract}
The purpose of the present article is to illustrate the crucial role played by the Umwelt theory in zoomusicological (and, more generally, zoosemiotic) studies. Too much, in fact too little, has been written on the relationship between non-human animals and music. Most of these writings do not explicitly aim at contributing to the actual problem (a good example being the reflections on birdsong contained in John Locke's Essay Concerning Human Understanding). Some are, so to speak, a little folkloristic, quite a few broach the problem in strictly scientific terms, and very few take a clearly zoomusicological approach. In an attempt to understand all the possible ways in which the problem can be analysed, it turns out that all these contributions in spite of their reciprocal diversity - have points in common, leading to three main categories of approach: discontinuity, gradualism, and pluralism (or Umwelt theory). The discontinuist attitude is by definition opposed to the intent of a zoomusicological research, which in fact defends the thesis that music is not specific only to humans. On the other hand, one might share the gradualist assumption that musicality departs from a basis common to many animal species (at least, all those provided with vocal apparatuses). However, such a basis cannot be interpreted as monolithic (i.e., as having developed in a unique and indivisible way), carrying, as a result, qualitative differences in music between species. For the above-mentioned reasons, and for others to be illustrated in the present paper, it becomes clear that the approach to zoomusicology must necessarily be pluralistic. The most suitable framework seems to be that postulated by Jakob von Uexküll, and known as the theory of Umwelt.
\end{abstract}




\section{A brief definition of zoomusicology}

The idea of zoomusicology, in the modern sense of the term, originated with François Bernard Mâche, in his Music, Myth, Nature. He announces that zoomusicology is "not yet born", thus establishing in actual fact its birth. Briefly put, the aim of Mâche's essay is to "begin to speak of animal musics other than with the quotation marks" (Mâche 1992: 114). His book first came out in $1983^{1}$, thus one can understand how little has been said until now about the subject, and how much remains to be said.

First of all, there is the problem of defining the discipline. If I was asked to define zoomusicology in a few words, in order to include this term in a dictionary, I would probably say that this discipline studies the "aesthetic use of sound communication among animals". This definition would have the following consequences:

1. I would avoid the use of that really dangerous word, "music". This is because such a concept must be handled with extreme care, even when related to human music only. If one approaches a not-yetdefined sound phenomenon and claims that such a phenomenon is musical, then one really must prove it.

2. I would include another dangerous word, "aesthetic". That is because a) although non-experts would hardly extend this concept to non-human animals, in actual fact, ethology, especially recently, tends to acknowledge the existence of an aesthetic sense in animals; b) most of all, at this very generic stage, the use of this word, as preferred to "music", is motivated by the fact that this expression represents a methodological presupposition, whereas the expression "music" constitutes the real theoretical goal. Indeed, concepts like musicality and musical culture still have too strong an anthropological connotation to be applied to the rest of the animal kingdom as well; c) the concept of "aesthetics", within my theoretical framework, is a fundamental presupposition for defining music.

3. By simply saying "animals", and not "non-human" ones, I leave open the possibility of including Homo sapiens in zoomusicological research. That is because a) as I already stated in the introduction, we should not forget that humans are animals, thus it is important to make clear that zoomusicology is not "opposed" to anthropomusicology, but

The excerpts quoted in this book are taken from the English edition of Mâche's work, published in 1992; the original version was issued in 1983. 
actually includes it; and b) if the analysis of human behaviour can also fall into the ethological domain, then human music can fall into the domain of zoomusicology. I am not envisioning a zoomusicological version of Desmond Morris's controversial The Naked Ape, but still I feel that a change of perspective can be scientifically healthy.

4. By saying "sound communication", I am explicitly declaring a semiotic approach to music. In this essay, I consider music as both a semantic and syntactic system. I will clarify this approach shortly.

Secondly, one might wonder about the raison d'être of zoomusicology; i.e., what consequences are implied in zoomusicological study? What is zoomusicology really putting up for discussion? Mâche provides an answer when he says that "if it turns out that music is a widespread phenomenon in several living species apart from man, this will very much call into question the definition of music, and more widely that of man and his culture, as well as the idea we have of the animal itself" (Mâche 1992: 95). In my opinion, such a statement implies a few interesting reflections. Zoomusicology approaches nonhuman animals from the direction of human sciences, and music from the direction of biological sciences. As I have already pointed out, certain changes of perspective can be quite helpful for a more complete overview of the phenomena analysed.

Moreover, the basic innovation provided by zoomusicology is the assertion that music is not an exclusively human phenomenon, but rather an emotion and instinct-based one.

If we had at our disposal sufficient studies of the neuro-physiological links between biological rhythms and musical rhythms, I would probably have been able to draw up arguments which reinforce the conception I am defending, that of music as a cultural construct based on instinctive foundations [...]. But if the animal world reveals to us precisely this emergence of music from the innate, this should enable us to compare it with what happens in man. (Mâche 1992: 95).

Hence, to adopt the zoomusicological paradigm means to put seriously into discussion the present definitions of music, starting from its strongly anthropocentric connotation.

At the same time, the whole conception of the nature-culture dichotomy is to be revised. Mostly, one should wonder - as Peirce 
already did in speaking of synechism - if we really have to consider it as a dichotomy.

Finally, on a more ethical level, zoomusicology, together with zoosemiotics, cognitive ethology and other studies, testifies to the encouraging progress of human knowledge in studying other animals. Hopefully, the disturbing ghosts of hardcore mechanism, behaviourism and evolutionism, will soon disappear, allowing humans to perceive and interpret other living beings in a more appropriate and realistic way.

\section{Gradualism, discontinuity and pluralism}

In an attempt to understand and classify all the possible ways in which the zoomusicological problem has been and can be analysed, it turns out that all the contributions - despite their reciprocal diversity in typology and reliability - have points in common, and lead to three main categories of approach: gradualism, discontinuity and pluralism (or Umwelt theory).

By gradualism is meant a generically Darwinian approach ${ }^{2}$. The idea is that of an evolutionary continuum in which the human being occupies the highest position, and in which, position after position, the characteristics of the diverse species are less and less complex and refined, although adequate for ensuring the survival of the species in question. In this sense, music, like language, intelligence and so on, is a unique and gradual structure, which finds its maximum development in human beings. This means that sounds uttered by other animals may easily be considered musical, but their apparently lower complexity, the lack of elements present in human music (musical instruments, written musical notation, etc.) and other such differences, are considered to be manifestations of a comparatively inferior development. Typical gradualistic attitudes are recognisable in those who consider birdsong as proto-musical, and who more generally maintain that the origins and rudiments of art can be traced to several animal species. For instance, Hamilton and Marler take a gradualistic approach when they declare: "we must also bear in mind the

2 Many of the references to Darwin in this essay are deliberately approximate, for they intend to recall a common idea on Darwininan theories, more than the real theoretical principles postulated by the British naturalist. 
possibility that some aspects of song variation [in birds] are a manifestation of some kind of primordial exercise in aesthetics" (Hamilton, Marler 1966: 446).

Discontinuity refers to an attitude that is generally sceptical, if not hostile, of the hypothesis that other animals possess an idea of music. The typical approach here is to emphasise a "discontinuity" in the evolution of human beings, in comparison with all other living beings. In other words, a sort of autonomous and peculiar development started at some point in the human evolutionary course, in a way that every behavioural element articulated from then on constituted an exclusively human characteristic. An example of discontinuity is the opinion that music is a typically human phenomenon, which has nothing to do with sound manifestations made by other animals. Such manifestations may sound like, but definitely cannot be music.

The discontinuist attitude is by definition opposed to the intent of the zoomusicological research, which in fact defends the thesis that music is not specific to humans only. In addition, I will explore the hypothesis of the Transpecific character of many musical elements, and the species-specificness of many others. In other words, I will share the gradualist assumption that musicality departs from a basis common to many animal species (at least, all those provided with vocal apparatuses). At the same time, however, such a basis is not interpreted as monolithic nor as having developed in a unique and indivisible way, carrying, as a result, qualitative differences in music between species.

For these reasons, and for others to be considered later, it becomes clear that the approach to zoomusicology must necessarily be pluralistic. The most suitable framework seems to be that postulated by the theoretical biologist Jakob von Uexküll, and known as the theory of Umwelt.

\section{The theory of umwelt}

Ask a human being to name a piece of furniture consisting of a smooth flat wooden slab fixed on legs. Most probably, the human subject will call such an entity a table. Now imagine posing the same question to a wood-worm. Possibly, the latter will describe this object as a big, wide, immense food area. The human subject and the wood- 
worm are facing the same entity, apparently sharing the same environment, are in the same area of the planet Earth, breathe the same air, and are surrounded by the same quantity and quality of matter and molecules.

Nevertheless, the human being and the wood-worm do not share the same Umwelt, i.e., the same subjective phenomenological environment. The wood-worm, because of its physical constitution, its modes of perception, its experience, and in relation to what is 'necessary', 'interesting' to its existence, interprets and (metaphorically) describes the surrounding environment in a totally different way than a human does. The human, in turn, has a given physical constitution, given perceptual possibilities, etc. In other words, although living in the same environment, human beings and wood-worms establish a different relation with it (a relation that is evidently semiotic). Humans and wood-worms see the same things as different objects. John Deely has explained very clearly the difference between an object and a thing:

[...] there is a great difference between an object and a thing. For while the notion of thing is the notion of what is what it is regardless of whether it be known or not, the notion of object is hardly that. An object, to be an object, requires a relation to a knower, in and through which relation the object as apprehended exists as terminus. A sign warning of 'bridge out' may be a lie, but the thing in question, even in such a case, is no less objective than in the case where the sign warns of a 'true situation' (Deely 2001: 129)

Cimatti (2001, personal communication) indicates the three basic implications of the Umwelt theory as follows:

1. What we might consider a stupid behaviour in another species, depends in reality on the fact that the animal in question values the same situation according to very different perceptual criteria. Literally, it sees different things than we do.

2. In order to understand non-human animal communication, we first need to investigate how they organise their own experience, i.e., what is pertinent to them and what is not.

3. Something interesting or pertinent for a non-human animal may not be perceived by humans at all.

Rather erroneously, the term "Umwelt" has often been confused with that of "environmental niche", or in other cases with "habitat", and in the most inattentive cases, with "environment". It is evident, 
though, that Umwelt does not designate a touchable and tangible category, but rather an array of phenomenological elements. As John Deely emphasises,

We see then how different and richer is the concept of Umwelt than the subalternate concept of 'environmental niche'. The concept of environmental niche simply identifies that part of the environment as physical upon which a given biological form mainly depends in deriving the physical aspects of its sustenance. The concept of Umwelt, by contrast, shows us how a given 'environmental niche' is merely the physical part of a larger, objective, not purely physical whole which is, as it were, fully comprehensible only from the perspective of the particular lifeform whose world it is, whose 'environment' is meaningful in the specific way that it is thanks only to an irreducible combination of relations many of which have no being apart from the lifeworld and all of which contribute to the contrast between the physical environment as neutral or common respecting all organisms, on the one hand, and parts of that same physical environment interpreted and incorporated within a meaningful sphere of existence shared by all the members of a species, on the other hand. Only things which are objects make up part of these species-specific worlds, but within these worlds are many objects which also are not things apart from the worlds. (Deely 2001: 129-130).

More specifically, Uexküll considers Umwelt as the result of two main elements: the Merkwelt, i.e., the specific perceptive field of a given organism, and the Wirkwelt, i.e., the field of actual interaction, the operational dimension of the same organism. Perceptual and operational factors contribute to form a specific Umwelt, which is exclusive for each species, and - proceeding by levels, and establishing adequate proportions ${ }^{3}$ - for each community, individual, class, family and so forth. To make the concept clearer, consider Fig. 1. On one side, an organism (e.g., a frog) takes part in a semiosis process, in which it plays the role of "receiver of meaning". On the other side, the environment that surrounds the frog functions as a counter structure, and the frog is related to it both from a perceptual and from an operational point of view. In the first case, receptors (senses) are important; in the second case, organs 'affecting' the

3 Uexküll conceives the idea of Umwelt in a biological framework, thus his reflections have much to do with specific differences. In practice, however, one may re-interpret, as many have already done - the whole concept under different lights: cultural, psychological, sociological, and so forth. 
environment — such as legs — become preeminent. The environment thus works as a "carrier of meaning", for it addresses receptive and operative messages to the frog.

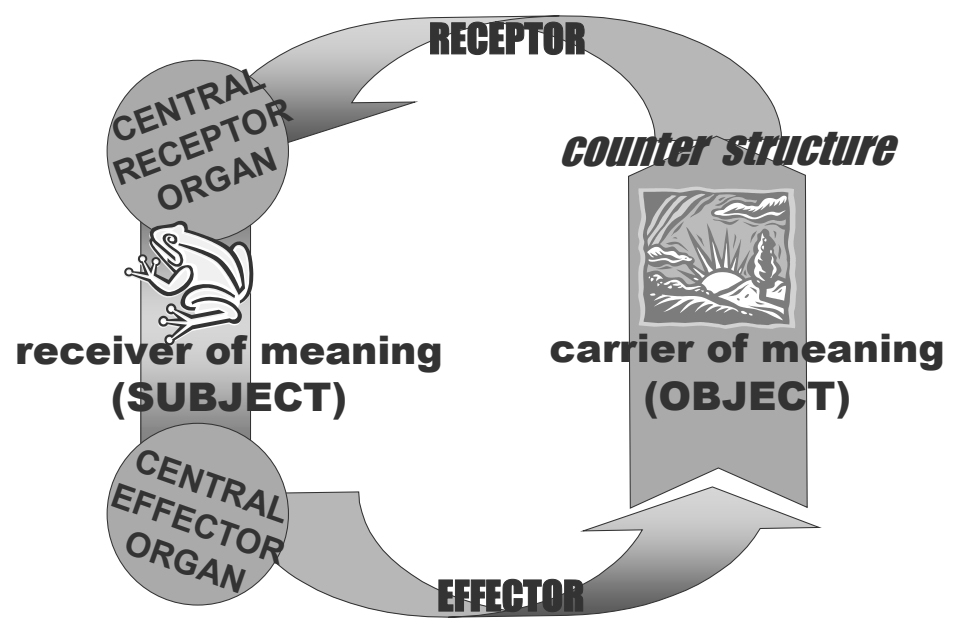

Figure 1. The Umwelt circle.

\section{Transpecific and species-specific traits}

How does the adoption of the Umwelt paradigm affect zoomusicology? Many aspects are to be considered here. First of all, to conceive the animal kingdom in the light of the Umwelt theory means at the same time to acknowledge transpecific and species-specific traits in the various species. The word "transpecific" refers to the musical elements that can be found in more than one species, even when among just a few. This level is important in order to show the common biological bases of musicality, and is definitely less problematic than the second level, since in most cases the analysis reveals great similarity between the species observed and human musical culture. The most banal example is of course singing, but other, more 
particularised aspects could be cited - such as non-human animals arranging sounds into a graduated scale (Mâche 1992; Schafer 1985; Martinelli 1999; 2001; 2002).

Elements are called "species-specific" when they present characteristics that are typical of the species observed. This level shows how musicality, despite the above-mentioned biological basis, has taken quite varied courses, according to the evolution of each species, and - most of all — to the articulation of the respective Umwelts. Of course, the less a species exhibits human musical traits, the more difficult musicological analysis becomes. This is because zoomusicology is just taking its first steps: it is natural that human musicality, for the moment, represents the only complete point of reference. When musical cultures of other animals will have been studied more closely, we will probably be able, through abduction, to create new musical parameters to apply to the most peculiar cases. A typical example of a species-specific trait is the number and quality of pertinent sounds and intervals that occur during a performance. The perception and use of these pertinences vary from species to species, so that - quite trivially - a sound that is catchy and pleasant to a dolphin's ear might sound totally out of tune to a seagull.

Such a distinction should also be considered useful in the area of rules and principles and not only in defining specific traits. For instance, the fact that wolves utter an arch-shaped melody (i.e., a prolonged sound that starts low in intensity - and quite often in frequency, too, then increases to a certain peak, and finally decreases again) is surely not a species-specific trait of that species (humans, to mention one species, occasionally perform in that fashion). Rather, the fact that that type of melodic pattern occurs so often as to make it a distinctive mark of howling can be considered species-specific.

Of course, one shall not deny how problematic the picture is in this case. To deal with the species-specific traits issue means to take a whole responsibility to tell what, in animal sound manifestations, distinguishes one species from all other existing on Earth. This is predictably a hopeless task. Even if it was not, the presence of millions of animal species on this planet would make this the thickest book ever. Thus, any attempt in this direction is doomed to failure anyway. What is more realistic, is to propose some methodological indication and — very cautiously — some hypothetical example. 
As already mentioned, by species-specific we mean an element (behavioural, physical or else) that must be considered exclusive of the species examined. The concept itself of exclusivity is however to be put into discussion, for matters of principle:

1. How to deal with the same element emerging in two different species, which presents the characteristics of a simple analogy rather than homology ${ }^{4}$ (in a few words, such an element fulfils a given function for one species and a totally different one for the other)?;

4 I have already pointed out that the aim of zoomusicology is to demonstrate that a concept of music (or aesthetics, more generally) exists in non-human animals as well as in human ones. In other words, my claim is that sound manifestations in non-human animals are homologous to musical manifestations in humans. They are not simply analogous. As Sebeok points out, "These parallels immediately raise several problems, the most obvious being whether the animal's behaviour is 'merely' analogous to man's, whether, that is, shifting to a more familiar parlance, [for instance] the label 'dance' is 'just' a colourful and suggestive metaphor - as it must surely be in Frisch's designation of the kinetic component of the communication system of the honeybee as a 'dance' - or whether something deeper is implied, perhaps indeed a remote phyletic homology 4 ", (Sebeok 1981: 218).

Let us consider three men holding up their hands. The first stands on a basketball court and has just scored a point. The second stands before the TV watching that basketball match and supporting the team which the first guy plays for. The third guy is somewhere else and has a gun pointed at his back, and to be sure, is not interested in basketball at all. The behavioural pattern (hands up) of the first guy is homologous to that of the second, and analogous to that of the third, since the first two cases are clearly a display of agonistic euphoria, while the third is just obedience to a robber's command.

The homologies-analogies issue, very typical in animal-related studies, applies also to ethnomusicological contexts. "[...] the facts inventoried in the sound material and considered identical by the musicologist do not necessarily have the same meaning for each of the autochthonous people who have played them [...]. It is very interesting to find analogies between a work by Messiaen and a Tibetan piece from the point of view of sound material perceived, but one must note that such a comparison - which might end up, why not, by finding universals retains a necessarily etic character" (Nattiez 1977: 99).

The problem of homologies is widely studied also in ethology, especially as concerns acoustic communication. According to Tembrock (1963: 777), there are three criteria by which to define homologies:

1. The criterion of position, understood as "the situation that exists at the time when the sound is made. This concept of 'position' would have to include all available external and internal factors" (Tembrock 1963: 777);

2. The criterion of the special quality of the structures; 
2. Is it acceptable to take into consideration elements that are actually exclusive of a given species, but emerging in totally isolated and sporadic situations, without any significant statistic continuity?; and finally

3. Is species-specificity the sole parameter to consider as opposed to universals, or order-specificity, class-specificity, individual-specificity etc. should be also considered?

3. The criterion of interconnection by intermediate forms.

These criteria refer directly to sound forms, and, in Tembrock's view, could be used in principle, if comprehensive data on acoustic communication in nonhuman animals were available.

Tembrock indicates further, auxiliary criteria that can be used for simple structures: "a) simple structures can be regarded as homologous if they occur in a large number of nearly-similar pieces; b) the probability of a homology in simple structures increases with the existence of further similarities of equal distribution in nearly-similar pieces; and c) the probability of homology of a characteristic decreases with the frequency of occurrence of this characteristic in species which are definitely not related" (ibid.).

Unfortunately, the fact that certain types of non-human animal behaviour may be considered either analogous or homologous to human behaviour does not only depend on the factors listed above. In some cases, the exclusive human-ness or non-human-ness of certain behavioural traits is simply taken for granted - e.g., music is claimed to be exclusively human - so that attempts to detect homologous characteristics in such patterns is a priori accused of anthropomorphism or zoomorphism.

Significantly, scholars supporting the aesthetic hypothesis in non-human animals must systematically stress that their researches are not affected by anthropomorphism. "[...] a natural recognition of the remarkable similarities which actually exist between the dances of birds and men and the identity of the emotional sources from which both take their origin. The resemblances between avian and human dancing are the outcome of emotional drives which underlie the behaviour of all the higher animals; and the natural corollary is that we can use the terpsichorean activities of men to interpret those of birds, and vice versa. Let us not be scared by the bogey of anthropomorphism into the arms of the spectre of Cartesian mechanism. It is not anthropomorphism to believe that man and the higher animals have much in common so far as instinct and emotion are concerned, but an acknowledgement of truth scientifically demonstrated" (Armstrong: 1963: 195). Provided that the analogies-homologies phenomenon can be demonstrated in the zoomusicological field (which is one aim of the present essay), I look forward to the time when one will not have to "justify" his/her own anthropomorphic tendencies, especially when they are not at all anthropomorphic in the common sense. 
On the first point, Sebeok seems to have quite clear ideas, even without explicitly dealing with the problem:

Although 'flehmen', or lip-curl, which involves the closure of nasal openings when the head is jerked back, is a widely distributed behavioural trait in mammals, this facial expression has evolved into a particular sign in horses which elicits particular responses on the part of other horses. A fearful rhesus monkey carries its tail stuck stiffly out behind, while a baboon will convey the same emotion to its fellows by holding its tail vertically. In brief, each kind of animal has at its command a repertoire of signs that forms a system unique to it or is, in biological parlance, species-specific. (Sebeok 1986b: 76-77)

In other words, if given patterns are displayed by more than one species with different functions, than they should be considered species-specific. In zoomusicological terms, this implies the transposition of musical traits from their structure to their function, which is quite an interesting point.

As for the second point, I will propose my personal reflections. When a musical characteristic is detected with more frequency than another, it does not necessarily mean that the former is more relevant than the latter. It is surely important to detect the recurrence of a trait, in order to understand how essential and distinctive this trait is to a species (or a community, or an individual). The very large number of solo piano pieces written by Chopin is a clear clue of how relevant that instrument was for the compositional process of the Polish composer.

On the other hand, the sporadic emergence of a given trait should not lead to the conclusion that such a trait is less or not significant at all. There is only one Queen song in which the classic drum kit is replaced by plenty of hand-clapping and foot-stomping, i.e., "We Will Rock You", but it takes a bit of courage to affirm that this song - a Queen standard - is not typical of or significant to the repertoire of the English rock-band. At the same time, an arched-shaped melodic howling is undoubtedly a frequent and characteristic trait in canidae, but from that we should not necessarily deduce that other, quasi-arch shaped forms of howling are melodic mistakes ${ }^{5}$. There are several

5 In fact they can be, if there is a way to demonstrate that precise arches are an aesthetic goal in canidae's howling, and thus "almost-arches" are a sort of presong, as occurs in birds. My claim here is that neither one nor the other conclusion can be made on a simply statistical basis. 
analytical levels to take into account: one is the transpecific, and another is the species-specific, but within the latter there are numerous cultural (i.e., related to the habits of a given community instead of one another) and individual nuances. The amazing variety of humpback whale songs is paradigmatic in this sense.

In addition, just the existence of a wide range of individual variations and styles makes zoomusicology an inexact science.

Obviously, the study of an animal species cannot be exhaustive. Just as the best singers are at the same time those in whom one finds the greatest individual variations, one must have access to numerous hours of recordings of a great number of different individuals, throughout their entire habitat, in different seasons and over many years. It is not surprising that the number of species for which this kind of work has been done remains minuscule. Generalisations still depend largely on the familiarity of the describer with the species described. (Mâche 1992: 98)

More to the point, the emerging of a trait, even when sporadic, shows that the species in question is in fact able to produce it (even through a single specimen). When a sportsman establishes a world record in a given discipline, he not only demonstrated that he is able to break that boundary in space or in time, but he also demonstrated that human beings are. Then, if that record happens to be undefeated for a very long time, it would be quite paradoxical to consider it as little significant just because it is isolated and episodic. As a consequence, my answer to the second question is yes: it is acceptable to take into consideration rarely-emerging elements.

Finally, although quite crucial, the third question must be temporarily left apart. It is very probable - sure, in fact - that other types of specificity (by order, by individuals etc.) must be taken into consideration, and that the simple species-specific/transpecific dichotomy is in fact inadequate. However, at present, zoomusicology is too young and this essay too limited to transcend human music as a point of reference. And Homo sapiens is notoriously a species, rather than an order, a class or else. At present, zoomusicological research is pushing the musical boundaries from the anthropological (i.e., species-specific) level to the generally zoological (i.e., transpecific) one. At the moment, these are the levels in questions. 


\section{Analytical levels}

Although much more similar to gradualism than to discontinuity, the Umwelt theory is undoubtedly a third way for zoomusicology. Music cannot be conceived as a unique continuum, simply divided by grades. To locate music on one level instead of another, implies the understanding of where exactly a sound utterance should be considered musical (human beings? great apes? primates? mammals? animals? living beings?) and also where (i.e., at which point) certain traits can be analysed in their specific autonomy.

If one interprets the musical process at the same level of any other process of semiosis between organism and environment, a fundamental principle of musical activity becomes quite clear: music is the result of an interaction between a subject and an object, between a structure and a counter-structure, between a receptor and a carrier of meaning. These two parts are in constant and reciprocal informational exchange. In fact, the exchange itself is the real generator of the musical phenomenon, since the latter would simply not exist if the subject was not affected by it and did not affect it. Any zoomusicological (and generally musicological) research should take into account such a conception, otherwise it risks perverting the essence of the musical phenomenon.

An excellent exemplification of this close structure-counterstructure bound in music is the theory of bio-acoustic relations. According to Dane Harwood, "human beings construct meaningful patterns from information in their environment, and [...] these patterns form the basis of complex bodies of knowledge represented in memory. Categories - names for classes of patterns which are useful in coding, and operating in, the real world - have meaning to the extent that they specify one concept rather than others which are viable alternatives" (Harwood 1976: 529). Philip Tagg refers to such categories as bio-acoustic relations. They occur between a subject and a musical object. These relations are detectable between the following:

1. (a) musical tempo (pulse) and (b) heartbeat (pulse) or the speed of breathing, walking, running and other bodily movements. This means that no one can musically sleep in a hurry, stand still while running, etc.; 
2. (a) musical loudness and timbre (attack, envelope, decay, transients) and (b) certain types of physical activity. This means, for example, that no one can make gentle or "caressing" kinds of musical statements by striking hard objects sharply, by singing jerky lullabies at breakneck speed, or using legato phrasing and soft, rounded timbres for hunting or war situations;

3. (a) speed and loudness of articulating tones and (b) the acoustic setting. This means that quick, quiet tone beats are indiscernible if there is a lot of reverberation and that slow, long, loud ones are difficult to produce and sustain acoustically if there is little or no reverberation. This is why a dance or pub rock band is well advised to carry its own "sound-space" with it, in the form of echo effects, to overcome all the carpets and clothes that would otherwise dampen the sounds the band produces;

4. (a) musical phrase lengths and (b) the capacity of the human lungs. This means that few people can sing or blow and breathe in at the same time. It also implies that musical phrases tend to last between two and ten seconds. ${ }^{6}$

If we accept such a theoretical framework - and Tagg's application of it to human musical experience is very convincing - it could be interesting to interpret animals' musical cultures as consequences of each species' musical-biological Umwelt. The articulation and the modalities of the sounds produced by humpback whales is a perfect illustration:

1. Velocity: If modern human life is characterised by numerous social rhythms, the movements of whales' life are much more regular. "The tempo is largo and maestoso, and it seems to proceed at the same pace of the waves. Maybe this is the rhythm the whales are most familiar with, since they live with it" (Payne 1996: 153, my translation).

2. Echo: It is apparent that whales are aware of deep underwater feedback. Several recordings catch them amusing themselves by uttering a peremptory sound and letting the echo do the rest. In human music, such effects are artificial, as in popular music one hears flangers, phasers, and wah-wahs. Among other things, it would be interesting to know if the boom in the use of these effects in the 1970s is somehow related with McVay and Payne's discovery of whale songs

From http:// www.tagg.org/texts.html. 
(1971). According to Murray Schafer, a relation of this kind actually exists (see Murray Schafer 1985: 60).

3. Cyclic nature of singing. One session may be composed by many, manipulated repetitions of the same song. A similar characteristic is hardly found among humans, who seem to be more interested in thematic repetition. Payne maintains that whales' songs are cyclic because almost everything in their life is cyclic: "The life of most cetaceans is cyclic. A whale calf, as soon as it is born, perceives the circular movement of waves. The bigger the wave, the bigger (and slower) is the circular trajectory passively followed by the whale. [...] Migration routes, in many species [...], are circular instead of straight back-and-forth [...]. Whales, as all animals, experience the daily rhythm of light and darkness, and the seasonal rhythm of cold and warm. They experience the changing of tides, as affected by the cycles of the moon's phases [...]" (Payne 1996: 19, my translation). I would add that the above-mentioned underwater acoustic effects shape the sound wave in a roundish fashion. A rock guitarist who uses a flanger on his electric guitar is usually seeking a rounder, more water-like sound.

4. Length of song sessions, or, more generally, the time devoted to singing. To my knowledge, there is no human society that sings nonstop for 22 hours;

5. Sounds and intervals. The number of sounds employed in a whale song is much greater than those used in the songs of humans, since the former sounds make use of intervals smaller than a semitone. As illustrated earlier, all of these microtonal sounds are likely to be significant for a humpback.

6. Manipulation of sound material. The tendency to transform and "play" with sound material is widespread among non-human animals. Such a tendency can be found in humans, but definitely not on a regular basis.

\section{Umwelt theory and biocentric approach}

Given such remarks, the question we now wonder about is whether a discipline like zoomusicology (or zoosemiotics in general), which practically deals with animal sound communication through (and thus accepting the idea of) the functioning of their cognitive process, 
should make do with anthropocentric methodological models ${ }^{7}$. One should say no, of course, but at the same time, is there any efficient

According to usual definitions, anthropocentrism interprets Nature as (a) an entity existing apart from and for the benefit of humans, so that (b) nothing in Nature can be considered in itself, autonomously from humans; and (c) it is ethically acceptable for humans and non-humans to be treated in different ways. In other words, Nature is not of interest (e.g., to conservationists and preservationists) because of its hypothetically intrinsic value, but just because of its instrumental value, i.e., the values it has for and to humans.

Most criticism against animal-related studies tends to emphasise that a totally impartial interpretation of animal behaviour is not possible, for observations are external to the subject of study and cannot avoid frames of reference that are typical of human interpretation of reality. In this sense, the approach is anthropocentric, i.e., concentrated on and mediated by the fact of being human. Such a statement deserves, however, specific reflections.

First, such forms of criticism are a little simplistic, and merely constitute a comfortable and socially shared (thus, stereotypical) way out of facing a problem that is in fact quite complex. It may be easy to speak of anthropocentrism as an apparently unavoidable form of interpretation of reality that affects scientific research; however, to mix all its nuances in the same big pot reveals a lack of knowledge on the topic. It is more proper to dissect the question into all its components in order to re-interpret anthropocentrism more accurately.

Secondly, I have the feeling that those who doubt the scientific validity of animal-related studies, because of the difficulty of avoiding anthropocentrism, often seem to be sceptical only about part of the story, while in a few other cases, animal-related studies seem to enjoy everyone's confidence. Very well known is the scepticism that surrounded and partially still surrounds Darwin's theories, but where are the sceptics when it comes to evaluate the very probable anthropocentrism of pharmacological research? Should they not be at least suspicious about transferring given data from non-human species to the human one so easily?

Lastly, these types of criticism are a little too defeatist. It is true that there is no way to avoid some elements of anthropocentricity, but is this an absolutely unbridgeable gap between scientific research and a correct interpretation of reality? Things are never all black or white: the impossibility of being totally objective and impartial towards a topic is not really a good reason to give up scientific research in general. Different degrees of impartiality, according to specific cases, can be achieved. The challenge is to tend towards absolute impartiality. Otherwise, not only animal-related studies but also $99 \%$ of scientific fields would not be scientifically believable.

The above considerations appear rather simple, if not banal. Yet when animal studies are involved, scholars tend to forget them quite often.

Hence, the very first question, Is there just one type of anthropocentrism, or are there more? In other words, How many ways exist to observe reality according to the criteria of interpretation and classification proper to the human being? My research suggests me that such criteria should be distributed on at least two layers: 
alternative, an Umwelt-based model, which I call biocentrism for reasons I am about to illustrate, which works on both theoretical and concrete levels? I believe there is, and in fact I believe that unconsciously or not - part or most of such a model is already used in scientific research (possibly, under different labels), the main problem thus being just that of systematising the different parts into a coherent and realistically applicable theoretical model.

An issue such as biocentrism deserves more than the general scrutiny I give it in this article. First, because concepts that are complex and crucial, in order to understand and regulate the human role in the ecosystem, could be made to seem a bit generic and banal.

default anthropocentrism and binary anthropocentrism. The latter, in its turn, can be divided into quantitative and qualitative types.

The first elementary level, default anthropocentrism, consists in the banal consideration that the subject who observes a given animal species is evidently a human being, with all its resources, limits and modes of categorisation. What we understand about a dog, for instance, is what we are able to understand, given the means that allow us to do. Technology does not (yet?) allow us to understand a dog the way, say, a pigeon would understand it. Such a consideration is not very different from statements like "Alvar Aalto is a great architect". Quite evidently, in pronouncing such statements, we are reporting one of our forms of interpretation of reality, founded on personal experience, education, culture, perceptive sources and so on. Now, this looks to me obvious, inevitable, and not dangerous. The other way round, however, could be dangerous, for it could mean the expressing of opinion without any point of reference or any code, resulting in a sort of perceptive anarchy. As long as an anthropocentric attitude is reduced to this very basic expression, no kind of scientific research runs the risk of being taken little seriously.

The second type is binary anthropocentrism. Here, the fact of being a different entity from the object observed (human, rather than another animal) produces a dualistic interpretation of reality, based on criteria of difference (qualitative anthropomorphism) and/or a strongly hierarchical identity (quantitative anthropomorphism), which puts the observer, and the group s/he belongs to, in a superior position in relation to the group observed. In the case of qualitative anthropocentrism, the observer-human being tends to distinguish him/herself from the non-human animal by means of either/or qualities, which is almost a causal relation (i.e., "humans do, ergo animals don't"). In the case of quantitative anthropocentrism (which is a post-Darwinian anthropocentrism in a way), the difference between human beings and other animals is expressed by means of quantities (more/less). Within this framework, a statement like "Unlike Gropius, Alvar Aalto is a great architect" is of qualitative type, while the statement "Walter Gropius is a good architect, but Aalto is definitely better" is quantitative. 
Second, because I also run the risk of using the wrong terminology. In particular, if zoosemiotics pertains to animals, why should I use a word like biocentrism, which actually refers to all living beings, including plants, and not the more appropriate term zoocentrism? And why not even ecocentrism, referring thus to the whole ecosystem? There are three possible explanations for my choice:

1. Very simply: there is not room enough to develop every single issue and to provide adequate terminological and conceptual explanations. Among the above-mentioned options, biocentrism is the most familiar and, theoretically speaking, the best defined. For my purposes, that should be enough.

2. One of my main theoretical sources for this section is the Finnish philosopher Leena Vilkka, who has exhaustively illustrated the three concepts (Vilkka, 1997: 37-83). According to her definitions, zoocentrism "covers the discussions in which the notions of higher animals and their value are central. Zoocentrism is the animalcentered, especially vertebrate-centered philosophy" (ibid.: 37). In zoosemiotics, invertebrates have a definite and important role (see the importance of zoosemiotic studies on bees' communication). If one accepts Vilkka's definition (which she argues quite convincingly), the concept of zoocentrism is too limited in this context.

3. Any scientific theory should always take into consideration its own possible developments. If a phytosemiotics exists (and it does), nobody can exclude, a priori, the application of certain zoosemiotic principle to plants, as well. I am not saying that we should, but simply stating that, in looking forward to further developments, it is wise not to take too solid a position.

Having accepted that, other considerations can be proposed. As a first step, the concept of anthropocentrism must be reconsidered. Indeed, the real core of the biocentrism-anthropocentrism problem is not, as one might expect, the dichotomy between instrumental and intrinsic value. Anthropocentrism is certainly an interpretation of Nature on the basis of its instrumental value, but this conception is not necessarily opposed to the idea of intrinsic value.

The concept of intrinsic value can be interpreted at least in three ways: a) as a quality or property that human conscience attributes to something, and that characterises this object as possessing a value in itself, not related solely to human interests, or solely to the value of the conscience that gives birth to it; 
b) as a property that emerges from the relation between an event and a conscience, in a relational-phenomenological fashion; c) in Platonic terms, as a totally objective value, inscribed in the objects themselves and independent of human evaluation (e.g., Nature's value existed before human conscience and will keep on existing when the latter disappears"). (Bartolommei 1995: 42; my translation, D.M.)

In environmental philosophy, these three interpretations may be separated or combined. If kept separate, mostly excluding the third, ontological interpretation, there is little contradiction with a default anthropocentric attitude. It is not problematic for an anthropocentrist to accept that Nature, in whatever form or manifestation, may have value in itself, if a distinction is made between humans as source and as centre of values (Bartolommei 1995: 43). In a way, default anthropocentrism is nothing other than anthropogenesis: what is said or thought by humans starts from the human interpretation of reality, but - and this is the point - does not necessarily have to be confined to humans. What is said and thought by — say - a supporter of Juventus Football Club is not a priori "Juventus-centric".

In other words, the condition of the subject who speaks must not be confused with the contents of his/her statements: anthropocentrists should easily acknowledge that if it is true that there is no value without someone valuing, it is also true that the value of the object is not reduced to the sole value it has for the one who values, nor to the value of this latter him/herself. In short, it is one thing if anthropocentrism is meant as negation of values independent and separated from human acts of evaluation; anthropocentric prejudice is another thing (i.e., the idea that everything on Earth is only a function of human values). (Bartolommei 1995: 43-44; my translation, D.M.).

It is evident that the value I am discussing here is the musical one. The thesis I defend is that just because human beings create and theoretically develop the concept of music does not constitute a sufficient reason to think that music is an exclusively human peculiarity. I illustrate this concept further on. What matters now is to point out the four basic implications of a biocentric musicology:

1. Hermeneutically speaking, Nature is to be divided into levels, organised as follows. Beyond a general common basis, here called ecological, whose constraints - such as being subject to gravity are shared by everything on Earth, there is a second, biological level, in which every living being is included. Eating and reproducing, for 
instance, typify humans and birds, insects and flowers, and so on. Things become more interesting on the third level, called the zoological or the transpecific, which concerns aspects held in common among the whole animal kingdom. At this point, more than one human conception is to be revised. This book, for instance, proposes that music is not an exclusively human domain. In a way, it is only a matter of complexity. In turn, complexity is a relative concept, since it should be proportioned to the respective needs of each species, or to their respective Umwelts. Fourthly, there is the level of characteristics that concern a single species (species-specific). An activity such as making a presentation with the use of transparencies must be considered an exclusively human skill, just as giving the exact position of a flower by a figure-eight dance is a skill-specific to bees. From the next level on, the course is quite clear for humans, but is yet to be well defined for other species. This is because the categories are now species-specific, and each species has developed a unique process. For most animals, including humans, this level is mainly social, but many species are not organised into societies at all. Thus, one should stop here.

2. In this research, the transpecific level must be considered the first meaningful category. Zoomusicology is concerned with all those musical features that are not exclusive to humans, but are shared among at least some other species, specifically, among those provided with vocal apparatuses. It can now be said that as a zoological phenomenon, music can no longer be analysed from an anthropocentric point of view, just as decades ago ethnomusicologists said that, as an anthropological phenomenon, music should not be analysed from a strictly Eurocentric point of view.

3. The species-specific level is so capacious that nobody should take this kind of research as being too zoomorphic. Homo sapiens retains its incredibly large number of exclusive aspects. The problem here is to arrange categories in the right position and proportions, and to create a more appropriate "cosmology". As Cimatti comments, "centripetal" tendencies must be balanced with "centrifugal" ones: "On the one hand, this centripetal tendency is positive, for it finally reminds us that we are animals, that our behaviour does originate from an immaterial entity, and - as a consequence - that we have clear responsibilities towards Nature. Of course, this tendency is good as long as we do not neglect differences, falling once again into an 
excess of anthropomorphism (a typical attitude of TV programmes). Non-human animals are very different from us, and I would also say that it is ethically wrong to say that we should preserve them since they are good, they take care of the children, and things like that. Animals are not good from our point of view, but definitely this is not the point. We should preserve the animals' world as itself, precisely because it is so different from us. I would rather say that biology reminds us that we all are similar — we all descend from other living forms - and different at the same time, just because every animal species is different from all the other, otherwise it would not be a species. So, this centripetal movement is not wrong, but it must be accompanied by an analogous centrifugal movement that reminds us of the biological differences of each species" (Cimatti 2001: personal communication, my translation).

4. As biomusicologists like Nils Wallin (1991) maintain, the study of music in its biological dimension can be very useful for understanding its real essence and development.

\section{References}

Armstrong, Edward A. 1963. A Study of Bird Song. London: Oxford University Press.

Bartolommei, Sergio 1995. Etica e natura. Roma-Bari: Laterza.

Deely, John 2001. Umwelt. Semiotica 134(1/4): 125-135.

Hamilton, William J.; Marler, Peter 1966. Mechanisms of Animal Behaviour. New York: Wiley \& Sons.

Harwood, Dane L. 1976. Universals in music: a perspective from cognitive psychology. Ethnomusicology 10(3): 521-533.

Mâche, François-Bernard 1992. Music, Myth and Nature. New York: Harwood Academic Publishers.

Martinelli, Dario 1999. Il canto della megattera: Una musica bestiale. Musica/Realtà 60: 37-55.

- 2001. Methodologies and problems in zoömusicology. Sign Systems Studies 29(1): 341-352.

- 2002. How musical is a whale? Towards a theory of zoomusicology. Helsinki: Acta Semiotica Fennica.

Nattiez, Jean-Jacques 1977. Under what conditions can one speak of the universality of music? World of Music 19(1/2): 92-105.

Payne, Roger N. 1996. La vita segreta delle balene. Milano: Mondadori.

Payne Roger N.; McVay, Scott 1971. Songs of Humpback Whales. Science 173: 585-597. 
Schafer, R., Murray 1976. The Tuning of the World. New York: Knopf.

Sebeok, Thomas A. 1981. The Play of Musement. Bloomington: Indiana University Press.

- 1986. Talking with animals: Zoosemiotics explained. In: Deely, John (ed.), Frontiers in Semiotics. Bloomington: Indiana University Press.

Tembrock, Günter 1963. Acoustic behaviour of mammals. In: Busnel, R. G. (ed.), Acoustic Behaviour of Animals. London: Elsevier, 751-786.

Uexküll, Jakob von (1899-1940). Kompositionslehre der Natur: Biologie als undogmatische Naturwissenschaft. Frankfurt: Ullstein.

- 1956. Streifzüge durch Umwelten von Tieren und Menschen. Hamburg: Rowohlt Verlag.

- 1967. Ambiente e comportamento. Milano: Il saggiatore.

Vilkka, Leena 1997. The Intrinsic Value of Nature. Amsterdam: Rodopi. Wallin, Nils 1991. Biomusicology. Stuyvesant: Pendragon.

\section{Музыкальный круг: теория умвельта применительно к зоомузыкологии}

Цель настоящей статьи - иллюстрировать существенное значение теории умвельта для зоомузыкологических (и шире - зоосемиотических) исследований. Много писалось о связи музыки и различных животных, но при этом мало внимания обращали на саму суть проблемы. Некоторые исследования относятся скорее к фольклористике, только немногие исследуют проблему научными методами и лишь одиночки используют зоомузыкологию. Несмотря на многообразие разных подходов, при ближайшем рассмотрении выясняется, что у них имеются общие точки соприкосновения, что позволяет выделить три главных подхода: градуализм, дискретность и плюрализм (или теория умвельта). Исходящий из идеи дискретности взгляд уже по своему определению противоречит принципам зоомузыкологии, так как последняя придерживается мнения, что музыка присуща не только людям. Градуалисткая точка зрения предполагает, что музыкальность базируется на основе, являющейся общей для многих видов животных (по крайней мере для всех тех, которые имеют голосовой аппарат). Все же такую основу нельзя считать монолитной (т.е. развитой единственным и неделимым способом), такой, которая бы могла быть основанием качественных различий в музыке разных видов. Самой подходящей кажется созданная Якобом фон Юкскюллом теория умвельта. 


\section{Muusikaline ring: \\ Omailma teooria, rakendatuna zoomusikoloogias}

Käesoleva artikli eesmärgiks on illustreerida omailma teooria olulist tähtsust zoomusikoloogilistes (ja laiemalt - zoosemiootilistes) uuringutes. Muusika ja erinevate loomade seostest on küll palju kirjutatud, kuid väga vähe on puudutatud selle sisulist probleemi (nagu ka John Locke'i käsitlus linnulaulust ta teoses Essay Concerning Human Understanding). Mõned käsitlused on pigem folkloristlikud, üksikud uurivad probleemi teaduslikus plaanis, ja vaid väga üksikud kasutavad otseselt zoomusikoloogilist lähenemist. Erinevaid vaateid ja lähenemisviise mõista püüdes selgub, et neil on - mitmekesisusele vaatamata - ühiseid punkte, mis viib kolme peamise vaateviisi eristamisele: gradualism, mittepidevus, ja pluralism (ehk omailmateooria). Mittepidevusest lähtuv vaade on määratluse kohaselt vastuolus zoomusikoloogiaga, kuna viimase püüdeks on kaitsta seisukohta, et muusika ei ole üksnes inimomane. Gradualistliku vaate järgi eeldatakse, et musikaalsus lähtub alusest, mis on ühine paljudele loomaliikidele (vähemalt kõigile neile kel on hääleaparaat). Ometi ei saa sellist alust pidada monoliitseks (s.t. ainsal ja jaotumatul viisil arenenuks), mis annaks aluse kvalitatiivsetele erinevustele erinevate liikide muusikas. Sobivaim raam tundub olevat Jakob von Uexkülli poolt sõnastatu, mis on tuntud kui omailma teooria. 